\title{
COMMUNITY GOVERNANCE FOR POVERTY ALLEVIATION
}

\author{
Sudarmo \\ Faculty of Social and Political Sciences, Sebelas Maret University; \\ E-mail: sudarmo63@yahoo.com
}

\begin{abstract}
The Al-Munawaroh Muslim is an Islamic communitygrowing in Gilingan urban area of Surakarta City. Most members of this association and many people living around the area were living in poverty. This situation was perceived as a common problem and challenge for the community to resolve it. The aim of this study is to discuss critically the contemporary evident on community governance in Surakarta in line with the Indonesian Constitution of 1945, the Law 13/2011, and the Presidential Decree 166/2014 and that of 96/2015. One case study of the religion-based association namely the Al Munawaroh Muslim of Surakarta has been examined with regard to the networks created by the community in delivering community governance. By using ethnographic method, this research showed that the community had capacity to govern common problem despite its limited capacity; it has capacity to provide sustainable public service for the poor because its leaders, advisers and experienced members were together able to create social capital including internal networks among its members and external networks with other institutions horizontally and vertically. Conflict of some officials of the community was unavoidable because of different interests and preferences among them in managing the resource they belong, and some membersof the communitywere to be self-interest resulting in distrust among the majority of the members to them. Although the community had a capacity of governance by providing public service for the poor with food material and financial assistances, it was not a substitution but a complement for the state role in alleviating poverty.
\end{abstract}

Key words: community governance, social capital, internal networks, horizontal networks, vertical networks.

\section{A. INTRODUCTION}

Poverty is a prominent feature in most developing countries including Indonesia. Poverty is a public issue, requiring solution. In line with the Indonesian Constitution of 1945 on Article 34 (1) that "Impoverished persons and abandoned children shall be taken care of by the State", and Article 34 (2) that "thestate shall develop a system of social security for all of the people and shall empower the inadequate and underprivileged in society in accordance with human dignity", the government is constitutionally obliged to address the problems of poverty.Consistent to the constitution mandate, the government has implemented policy of poverty reduction mainly since the New Order Suharto until the Reformation era Joko Widodo.

The policies on poverty reduction continue to run with funds spent were reaching to trillions of rupiah.In dealing with the eternal poverty, the government enacted Law No. 13 Year 2011 on 
Poverty Management. Stated in the preamble of the Act that "the State is responsible for looking after the poor to meet their basic life needs for humanity", and "to carry out the State responsibilities, it requires national development policy which is planned, purposeful, and sustainable in favor of the poor".Despite the previous government policies of poverty reductions, the number of poor people in Indonesia was still high, around $11 \%$ of the total population over the last three years since 2014. Data from the Central Bureau of Statistics showedthat in September 2014 there were 27.73 million poor people. The figure rose to 28.51 million in September 2015 or an increase of 780 thousand; and in March 2016 the figure was only slightly decreased to 28.01 million or equivalent to 10.86 percent of the total population of Indonesia.

The endurance of high rates of poverty shows that poverty has not been completely resolved by the government for over 70 years since this country gained its independence in 1945 . Due to the powerlessness of government policies to address poverty, then comes the idea that the legitimacy of the state began to fade while the community began to gain attention as potentially capable of overcomingpublic problems (Newman, 2010; Smith, 2010; Alcock, 2011; Evans, 2011). The waning legitimacy of the State and the market has created a 'convergence of neoliberalism and communitarianism in forming a new relationship between the State, Market and Civil Society', assuming that the community may be able to resolve the problem that has not been able to be undertaken by the state and the market (private) for specific reasons such as shortage of human resources and the lack of accurate information (O'Toole and Burdess, 2004: 434). Thus the existence of the community can actually help minimize the state weaknesses in distributing resources to the citizens who are eligible to deserve it.

The basic idea of community governance is that the community is part of good governance because the community was able to overcome certain problems that cannot be handled by individuals alone or by the market and the government (Bowles and Gintis, 2002). Community governance aims to build and encourage a collective identity in the local authority (Banner, 2002). The core element of community governance is social capital (Halsall, 2012).

Social capital is a characteristic of the social life of a community that could be networks, norms and trust, which allow participants (those involved in the community) act together so that it is effective to achieve common goals; Thus, social capital is the relationships and linkages between the norms held by community members and their networks and trust each other between those involved (Putnam, 1995).In order for social capital to work effectively, it must be practiced 
efficiently in the governance of the community because idea about social capital is closely related to governance, where there is a strong relationship between the 'elements of social capital and governanceeffectiveness' (Skidmore et al. 2006). The growing practice of social capital means that the implementation of good governance is getting better (Putnam, 1995). The success of social capital is characterized by the growing number of institutions involved and of the vast opportunities for the public to be included (Halsall, 2012). In order to be successful then, the community must build a network in the forms of bonding, bridging and linking social capital (Pretty, 2003; Falk \& Kilpatrick, 2000; Flora, 1998). Bonding social capitaldeals with the strengthening of the internal network among the community members in order to create its solidarity, solidity and cohesiveness by implementing clear norms and sanctions for its members; bridging social capital is the creation of networking by the community with individuals, groups or any other non-government institutions outside of it with the aim that its existence is able to survive and provide better resources of services forits members and the public whilst linking social capital respects to network built by the community to outsiders affiliated state institutions such as the university or the government (Pretty, 2003).

\section{B. PROBLEM STATEMENT}

This paper discusses how theassociation of Al-Munawaroh Muslim (AAMM) in Surakarta as a religion-based groupdelivers community governance through the development of social capital in order to alleviate poverty for its members and those who are not the member including the moslem and the non moslem people living in the around of Gilingan urban area of the Surakarta City as a response of government incapability to address poverty relevant to the Law No. 13 of 2011. The Article 2 of the Law No. 13 of 2011states that "governance of the poor is activity of directed, integrated and sustainable attempt conducted by central government, local government, and /or society in the forms of policy, programs and empowerment, mentoring and facilitation to meet basic needs of every citizen". This means that addressing poverty is not merely a government monopoly and also considering the facts that the government has not been able to overcome the problem of poverty completely. Thus the activity of social capital created by the community in order to reduce the burden of the poor is consistent with the mandate of the Constitution of the Republic of Indonesia in 1945, Article 2 of Act No. 13 of 2011, the Presidential Decree No. 166 of 2014 about the program to Accelerate Poverty, the Presidential Regulation No. 96 of 2015 on Amendment of Presidential Regulation No. 15 year 2010 on the 
Acceleration of Poverty Reduction, which clearly states that the community is one important element in addition to the government and the business actors that should be involved in the program of poverty alleviation in Indonesia.

\section{RESEARCH METHODS}

This research was conducted in the urban area of Kelurahan of Gilingan of Banjarsari District ofSurakarta City. It used qualitative approach of ethnographic methods, combined with a quantitative approach but it was only as a support for a qualitative approach in order to strengthen the accuracy of qualitative analysis. The population of this studywas all members of AAMMas many as ninety people consisting of men and women, and the non-member consisting of 10 Moslem and 10 non-Moslem people who were the beneficiaries of AAMM'sservices over the last three years and they were all women.

Samples of this study were all the population but of the questionnaire given to the respondents only 86 questionnaireswere returned with a complete answer. The questionnaire included a list of questions with limited choices and closed answers. While the non-member samples for beneficiaries of AAMM include fourmoslem and six non-moslem respondents. Data were collected through participant observation in the period of 2000-2004 and 2008-2016 between from 200and in-depth interviews with a purposive sampling. To maintain the research validity, data was analyzed based on triangulations of data sources and methods.

\section{DISCUSSION}

\section{Development of the Association:1990-2004}

The AAMMwas established by retired civil servants who were local Moslem activists namely Suprapto, Sukiyo and Sarjono in 1990. During the period 1990-2004 the number of members reached about 60 people spread over a number of Citizen Associations (Rukun Warga) and Neighborhoods (Rukun Tetangga) in the Village of Gilingan. They generally consist of the retired civil servants, employees of private enterprise, street vendors, casual worker and one person who are an employer (developer). At its inception, the average age of members was between 42 and 71 years old. In this era, the community was led by Mr. Suprapto, a former civil servant in the department of religion Surakarta. In this era, Islamic teaching forum (ITF) wasperformed routinely every Thursday night. During this era, there was not idea of collecting 
cash donation to the members of the AAMM. The ITF was carried out from house to house, and only four members were willing to their houses to be occupied for ITFactivities, so that they would serve the forum activities once in every month and the four memberswerewell-known as thecentral proponents of the AAMM, and they were the backbone for the continuity of AAMM activities. One of them, the developer, wasthe most reliable because he was a very rich and generous businessmanwhilst most members of AAMMwere lower middle class; many of them were living in poverty and unable to fulfill their basic needs for themselves.

During the period 1990-2004 the AAMM had created harmony and solidarity among its members. The relationships between officials and members of the CFAMMwere very harmonious representing family bonds. The ITF activities were performed routinely; and strong relationships among the members were created until the chairman and the Islamic teacher, Suprapto could not run his activities anymore since the age of 85 years as he suffered fromseriously illness for four years since 2004 and died in 2008 at the age of 89 years.

\section{The Decline of Association Participation: 2004-2008}

Since Suprapto could not participate in the ITF actively due to serious illness in 2004, the leadership of the ITF was run by Sukiyo. In this era,the ITF activities continued in rotation from house to house but its intensity decreased sharply; it was carried out once every two weeks and the number of participants on average was only about 25 people. However, because Sukiyo was getting older he could not carry out his duties and functions as chairman of the forum since the beginning of 2008. Since then, the ITF activities weresuspended because there was no member who appeared to be the leaders who were able to move it. As a result, the level of memberparticipation in the forum dropped dramatically during this period.

\section{The Creation of Networks Since 2009}

In early 2009 the community began to bounce back after a 32-year old young man with adequate religious knowledge named Supandi and one person of former head of the neighborhood named Sugiyono, joined with the forum and led it. In this period generally the AAMM has performed a number of activities that can be classified into three categories namely: strengthening of the internal network among the members of the community; development of horizontal networks with non-governmental parties or communities whose equal stat us; and 
creation of vertical network with parties outside the AAMM affiliated to the government. All these buildings of networks were intended to improvethe provision of public services for the membersand the non-members of the AAMMincluding the poor Moslem andnon-Moslem.

\subsection{The Strengthening of Internal Network}

The first thing conducted by Supandi-Sugiyono in order to improve the internal conditions of the AAMMwas formingthe management board consisting of: Chairman (1 person), secretaries (2 people), treasurers (2 people), public speech ( $\left.d a^{\prime} w a h\right)$ affairsdeputies(2 people) and publicaffairsdeputies( 2 persons). This is done due to the shared concern of all members and their consensus to form the managerial board in early 2009. With the permission of all members, the board raised the advisers of 7 people with the youngest is 50 and the oldest is 80 years old. In carrying out its operational functions, the entire board was involved, except advisors. The advisors will be involved if the board is not able to find a way out to overcome the problem.

Secondly, the board is assisted by advisors to identify the members of the AAMM who could serve his or her place for ITF rotation. Therefore, the board and advisors classified members of the community who have a high socioeconomic status. Finally they found eight members who are economically and socially strong, ready and willing to fully support the system of ITF rotating from house to house; and they also found five other members who are willing to be a backup if the other is absent.

Third, formulate a program and run the routine activities of the community. Such activities include: (a) ITF activities routinely scheduled every Thursday night which is packed together with Isyaprayers congregation, from house to house; (B) anniversary of Islamic daysespecially Nuzulul (Revelation) of the Qur'an and the Isra'Mi'raj (Ascension) followed by donations to orphans, widows and the poor in the form of money or food; (C) the distribution of sacrificial animals meat, and (d) financial charity provided for the AAMMmembers who are in hospitalization or childbirth.

\subsection{External Network Development}

The creation of external networks includes two categories of horizontal networks (bridging social capital) and vertical networks (linking social capital). In strengthening horizontal networks the AAMM created cooperation with other ITF or communities especially communities of AlHikmah and Al-Ikhlas whose all members were women. All members of the AAMM who 
arewomen learn together with the community of Al-Hikmah on every Wednesday evening with the study subjects are Islamic jurisprudence and prayers organized by teachers from Al-Hikmah but free at no charge. The cooperation between AAMM and Community Forum of Al-Ikhlas focused on reading and writing the Qur'an and its translation as well as English lessons for all practical purposes and to talk everyday, with teachers coming from the Al Ikhklas forum but free at no charge. The cooperation had made the members of the AAMM are increasingly literate in reading and translating the Qur'an, getting to know the English language and deepening an understanding of practical jurisprudence and prayers. The educated members weregiven the opportunity to share knowledge for their routine meeting at the AAMM forum. In addition the AAMM also cooperate with other Islamic communities outside the Gilingan village of the Banjarsari District in terms of exchange of the ustadz (Islamic religion teacher) to providespeech regularly.

The strengthening of vertical network was carried out by encouraging members who have affiliation to the institutions of government to build cooperation with it. The AAMM could eventually cooperate with the Board of Research and Service for Community Universitas Sebelas Maret (LPPM UNS)to provide food and financial assistance to the poor in August 2016 with total budget reach to the amount $\mathrm{Rp} 15$ million. The activity has been planned to be held again in 2017.

The AAMM wasalso trying to increase wider network with other scholars and researchers in addition to the Universitas Sebelas Maret in the hope they could provide sustainable financial support for the continuity of the AAMM's activities. Other vertical networks were created by building linkswith the head village of Gilingan and his staffs, Chairman of Citizen Association and Chairman of the Neighborhood in social activities including healthy walk, blood donor in the independence day ceremony of the Republic of Indonesia every August 17 and invitations specifically to them to attend the rite of Nuzulul Qur'anand the ceremony of Isra 'Mi'raj along with sharing donations to the poor.

\subsection{Association Public Services for the Poor}

There is a routine service provided by the AAMM forits members who are in poverty to borrow cash donation. The cash donation reached 10 million Rupiah by the end of 2009 because of financial contributions from members and monetary support from the leaders of AAMM. All 
members who are in economic emergency condition are eligible to borrow cash donation up to Rp 1000.000 per person and it must be returned within three months. The members who borrow it generally follow the determined norms. However, it is known that there are three members of the borrower's cash since the end of 2009 until August 2016 did not return it to the total loan of Rp.3.000.000. These three people also borrow money to other members with the amount varied between Rp. 1,000,000 and Rp2,000,000 but never returned it. This condition has caused displeasure among the AAMM members.

Given the cash donation of the forum was large enough, one of management board members wanted the money to buy uniforms for all members and spent it for recreation outside the city. This idea was opposed by another board member because it was assessed as representing an ignorant attitude to the main goal of the forum intending to provide service mainly for the members and non-members who are poor. The idea willalso drain the AAMM financial resource so that it may deteriorate the association to run its main activity. Although conflict between the members of the boards was not manifested, potential conflict among them still persists because of different interests and values.

The AAMM services to its members further increased, i.e. not just access to loans against cash donation but also donations on the great day of Islam, especially on the anniversaries of the Nuzulul Qur'an and the Isra' and Mi'raj conducted since 2010. At this event also awarded compensation to moslem and non-moslem people who were not the membersof the AAMM. They are classified as people who were entitled to receive compensation according to the criteria of the CFAMM; theyconsisted of single mothers or married couples with total earnings below 1 million rupiah per month with the number of children up to 2 people or between 1-2 million rupiah revenue with more than 2 children; orphans who are looked after by their grandmother or grandfather with uncertain income but below 1 million per month; and widows or couples who have an insane or sickly child so that their economic life disrupted. The number of AAMM members who meet these criteria reach to 60 of 96 KAMM members as of August 2016, and 36 out of the 60 people were identified as the boropeople (migrants) and do not have access to assistance programs of the local authorities such as the government program of rice for the poor (Raskin) and direct cash assistance program through other social safety network of local government policy. They have been living in Solo City for years but they have not beenofficially 
registered as a formal resident of Solo while they are also not listed as recipients of assistance programs in their native region as they had been leaving their area of origin for long time.

The AAMM had tried to increase the quantity of the target beneficiaries and the amount of rupiah given. The average number of people who are able to be assisted by the CFAMM as many as 24 people with a total compensation of $\mathrm{Rp} 500,000$ per person in each activity since 2010 until 2016 including ten people consisting of 5 moslems and 5 non-moslemswho are not the AAMM members. Compensation for the poor rose sharply, especially when the AAMM was successful to make cooperation with the LPPM UNS in August 2016, bringing the total number of people who are able to be assisted reach to 61 poor people including 36 members of the AFAMM who were boro people (migrant) but long settled in Surakarta, 15 members of the AAMM with formal citizenship of Solo, and 10 were not the associationmembers consisting of 4 moslems and 6nonmoslem people.

Other services were also carried out in the form of distribution of sacrificial meat. Every year since 2011 until September 2016 the members who sacrificedwere coordinated by the board of AAMM, and was able to collect 5-6 goats and two cows with each cow is a fee of 7 members. The meat of sacrificial animals was distributed to all members; and others were given to citizens who were not members including those who were Islamic and non-Islamic citizens around the village of Gilingan. The average number of beneficiaries reached more than 100 people in any implementation of sacrifice, while the meat they earn can be enjoyed for 4-6 days.

The AAMM also provided compensation for members undergoing treatment in hospital through community cash amounting to $\mathrm{Rp} 300,000$, and most members of the community voluntarily assisted the patient with the amount collected about 1-2 million rupiah. Also the AAMM providedfinancial assistance for those who gave birth through cash money amounting to Rp 250,000 and individual voluntary contributions from members reached about 1-2 million rupiah.

\section{Development of Social Capital}

The above discussion informs that leadership periodization 2004-2008 was more emphasis on bonding social capital, while activities with outside parties has not been established yet. Although the bonding social capital is important, it is not sufficient as a network of communityas a whole (Flora, 1998; Kilpatrick, Field and Falk, 2003). 
The leadership of the AAMM has experienced major changes in community governance since 2009. The Board of the AAMM has been creating not only bonding social capital as was routinely done in the leadership periods of 1990-2004 and 2004-2008 but also bridging and linking social capital. Thus, it is clear that the ability to run a network through bonding, bridging and linking social capital is strongly influenced by the ability of the board or leaders in the community because the leaders are required to be able to find a way to connect between the experiences of a single element with other elements (Henocque, 2013).

A community will be able to effectively address the problem it faces if it is running not only bonding social capital but also bridging and linking social capital (Pretty, 2003; Woolcock, 2001; Kilpatrick, Field and Falk, 2003; Flora, 1998). This is because by doing bonding social capital means that community is able to strengthen network among the members of the community internally in order to establish the solidity, solidarity and cohesiveness of the community members and apply norms of the group and build trust among the members. Similarly, by creating bridging social capital or horizontally relationshipsmeans that the community is building networks with other communities that have equal status so that they can share information or resources. Also, by linking social capital means that community is building networking with other institutions such as governments, universities or any other public institutions that have a resource abundant and not owned by the community so that they can provide assistance when needed in order to provide services to members or other parties that will be served (Flora, 1998).

Although the quantity of the resources allocated by the AAMM still relatively small and limited, the development of 'social capital' which has been conducted since the beginning of 2009 can be regarded as a form of 'community responsibility' to the surrounding community (Putnam, 2004) and also a 'footpath toward the community prosperity and justice '(Cantor, 2007). The social capital created by the AAMM had also enabled coordination and cooperation for communal benefit of the diverse parties involved (Putnam, 1993), contributed to the social economic well-being of the community members who live in poverty (Falk and Kilpatrick, 2000) and accelerated the community and other parties involved in its networks to act collectively (Wolcock and Narayan, 2000). Thus how communities such AAMM has a very important contribution to alleviate poverty, especially in developing countries where poverty rates are still high. This is consistent with research World Bank which confirmed that social capital has an important role to reduce poverty in developing countries (Narayan and Pritchett, 1997; Krishna 
and Uphoff, 1999) so that communities like the AAMM is important to be developed and supported as part of central stakeholders in a regional development policy to alleviate poverty (Mouque', 1999)in Indonesia.

The AAMM have tried to create networks vertically (linking social capital) with other parties including universities, local government,neighborhoods, citizen associations and networks horizontally (bridging social capital) with other community of Islamic teaching or other communities whose equal status. However, not all the members of the community have the capacity or sufficient resources to assume responsibility demanded in a partnership, so it can cause their dependence on outsiders and encourage the State still hold mechanismsof 'safety net and compensation' (Halsall, (2012). Despite its significant role, community governance conducted by the AAMM to overcome poverty in the community through social capital is not a substitute' to the State's role in providing public services for the citizens, but it is a 'complement' to the role of the State through its participation together with the government to address poverty in its neighborhood (Bowels and Gintis, 2002). Similarly, the community ability to provide public services in the long term will be challenging because of limited resources they have, while the network is built not necessarily to be successful and sustainable, so that at any moment it might not be able to solve their own problems and returned to rely on outside parties mainly the government.

In the dynamic of social capital it does not mean that the community governance can always run smoothly and sustainable because whatever the community such as the AAMM, it is not so simple; it has different levels of structures and competing parties leading to conflict due to hidden self-interest among them (Bukari, 2013; Pelled, 1996; Mintz and Geva, 1993; Jehn, 1994) which can sometimes be destructive to the community when it was not managed properly (Deutsch and Coleman, 2000; Kriesberg, 1998). Any community including the AAMM cannot escape from the global process that is much larger and complex (Henocque, 2013). Similarly, the causes of poverty are also complex (Mwamuye, 2014), which may include individual shortcomings; cultural belief systems that reinforce sub-cultures of poverty; geographical gaps; and accumulative and repeated interdependencies (Bradshaw, 2005). Thus, despite its ability to create horizontal and vertical networks with others and able to provide sustainable material and financial assistance for the poor, the AAMM is not able to resolve the complex problem of poverty individually because the nature of poverty can only be addressed collectively and 
collaboratively; it is not just the community, government, private or international party individually but also includes a variety of stakeholders including the interests, commitmentand efforts of the poor themselves; community is only a complement of a variety of the stakeholders (Bowles and Gintis, 2002).

\section{CLOSING}

\section{Conclusions}

In line with Law No. 13 of 2011 Article 2; the Presidential Decree No. 166 of 2014, and the Presidential Decree No. 96 Year 2015, the community has ability to conduct governance and provideservices in order to overcome the problem of poverty for its members and residents of its surrounding areas through the development of internal networks (bonding social capital), horizontal networks (bridging social capital) and vertical networks (linking social capital). The community does not the substitute for the government, but it complements the role of government. In a broader context, the community has a complementary role in addressing the problem of poverty together with other stakeholders since the causes of poverty are complex so that it is insufficiently addressed by a community individually.

\section{Suggestions}

Local communities have capacity but it is limited. They have accurate information about the condition of the community and their environment, including information about the number of people living in poverty. Therefore, they are very decent to be involved by the government in the implementation of poverty alleviation programs so that the programs can be implemented effectively.

Similarly, there are many other religion-basedcommunities developingin Indonesia paying attention to the issues of poverty alleviation. If every community growing in this country competesto perform governance of the same issueand createnetworks with various other parties, this condition maylead to overlap activities accumulated on the same target group or even conflict of interests. Therefore, the community activities in delivering governance requires not only coordination and collaboration among the partiesbut it requires the state involvement particularly as the subject of governance requires rule of law for program implementation. However, the ordinance of functioning governance by community in addressing the problem of 
poverty has not been regulated in detail in the Act No. 13 of 2011; Presidential Decree No. 166 of 2014; and the Presidential Decree Number 96 Year 2015.

Given the important role of the community in helping to address the problem of poverty, the government needs to provide a clearer and more detailed legal guidance in the future so that governance of community can be directed, coordinated, integrated and synergistic with the programs undertaken by the government and other non-government institutions including community and private.

\section{F. Acknowledgements}

I am indebted to the foundersof the AAMM for their excellent support. A special acknowledgement should go to the board, chairman, teacher and members of the AAMM, theAssociationof Al-Ikhlas, theAssociation of Al-Hikmah, the Chairmans of Citizen Associations and the Neighborhoods, the head village of Gilingan who have supported a whole set of this research.

\section{BIBLIOGRAPHY:}

Alcock, P. 2010. Building the Big Society: A New Policy Environment for the Third Sector in England. Voluntary Sector Review, Vol. 1 No. 3: 379-389.

Badan Pusat Statistik. 2016. Profil Kemiskinan di Indonesia, Maret. Jakarta.

Banner, G. 2002. Community Governance and the New Central-Local Relationship. International Social Science Journal, Vol. 54 No.172: 217-231.

Bowles, S. and Gintis, H. 2002. Social Capital and Community Governance. The Economic Journal, Vol. 112: 419-436.

Bradshaw, T. K. 2005. Theories of Poverty and Anti-Poverty Programs inCommunity Development, Human and Community Development Department, University of California, Davis

Bukari, K.N. (2013). Exploring Indigenous Approaches to Conflict Resolution: The Case of the Bawku Conflict in Ghana, Journal of Sociological Research, Vol. 4 No. 2: 86-104

Cantor, C. N. 2007. Building Social Capital with Bonds and Bridges. Speech delivered at the Foundation for the Carolinas Annual Meeting, Charlotte, North Carolina, February 15.

Deutsch, M. and Coleman, P. (eds.). (2000). The handbook of conflict resolution: Theory and practice. San Francisco: Jossey-Bass.

Evans, K. 2011. Big Society in the UK: A Policy Review. Children and Society, Vol. 25 No. 2:164-171.

Falk, I. and Kilpatrick, S. (2000) What is Social Capital? A study of a Rural Community, Sociologia Ruralis, Vol. 1 No. 40: 87-110.

Flora, J. (1998) Social Capital and Communities of Place: Presidential Address, Rural 
Sociology, 63, pp.481-506.

Halsall, J. P. 2012. Community Governance - Where did It Go Wrong? JOAAG, Vol. 7. No. 2. Henocque, Y. 2013. Enhancing Social Capital for Sustainable Coastal Development: Is Satoumi the Answer? Estuarine, Coastal and Shelf Science, Vol. 116 No. 1: 66-73.

Jehn, K. 1994. Enhancing effectiveness: An investigation of advantages and disadvantages of value- based intragroup conflict. The International Journal of Conflict Management, Vol. 5: 223-238.

Kilpatrick, S., Field, J. and Falk, I. 2003,Social Capital: An Analytical Tool for Exploring Lifelong Learning and Community Development British Educational Research Journal, Vol. 29, No. 3, 2003: 417-433.

Krishna, A. and Uphoff, N. 1999. Mapping and Measuring Social Capital: A Conceptual and Empirical Study of Collective Action for Conserving and Developing Watersheds in Rajasthan, India, Social Capital Initiative Working Paper No. 13 (Washington, World Bank).

Kriesberg, L. 1998. Constructive Conflict: From Escalation to Resolution. Lanham, MD: Rowman \& Littlefield.

Mintz, A. and Geva, N. 1993. Why Don't Democracies Fight Each Other? An Experimental Study. Journal of Conflict Resolution, Vol. 37 No. 3: 484-503.

Mouque', D.1999. Sixth Periodic Report on the Social and Economic Situation and Development of the Regions of the European Union. Brussels, European Commission.

Mwamuye, M. K. 2014. Poverty Definition and Its Contribution to Projects Failure in Kilifi County, Kenya.Global Journal of Politics and Law Research. Vol. 2 No. 2:.27-38.

Narayan, D. and Pritchett, L. 1997. Cents and Sociability: Household Income and Social Capital in Rural Tanzania, Policy Research Working Paper 1-41 (Washington, World Bank).

Newman, J. 2010. Towards A Pedagogical State? Summoning the 'Empowered' Citizen. Citizenship Studies, Vol 14 No. 6: 711-723.

O'Toole, K. and Burdess, N. 2004. New Community Governance in Small Rural Towns: the Australian Experience. Journal of Rural Studies, Vol. 20 No. 4: 433-443.

Pelled, L. H. 1996. Demographic Diversity, Conflict, and Work Group Outcomes: An Intervening Process Theory', Organization Science, Vol. 7 No. 6: 615-631.

Peraturan Presiden Republik Indonesia Nomor 166Tahun 2014 Tentang Program Percepatan Penanggulangan Kemiskinan. URL: www.hukumonline.com. Diakses secara online 7 September 2016.

Peraturan Presiden Republik Indonesia Nomor 96 Tahun2015 Tentang PerubahanAtas Peraturan PresidenNomor 15 Tahun2010TentangPercepatan PenanggulanganKemiskinan. URL: www.hukumonline.com. Diakses secara online 7 September 2016.

Pretty, J. 2003. Social Capital and the Collective Management of Resources. Science, Vol. 32: 1912-1914.

Putnam, R. D. 2004. Using Social Capital to Help Integrate Planning Theory, Research, and Practice. Journal of the American Planning Association, Vol. 70 No. 2: 142-51.

Putnam, R. D. 1993. Making Democracy Work: Civic Traditions in Modern Italy .Princeton: NJ, Princeton University Press. 
Putnam, R. 1995. Bowling Alone: America's Declining Social Capital, The Journal of Democracy Vol. 6 No. 1: 65-78.

Skidmore, P., Bound, K. and Brough, H. L. 2006. Community Participation: Who Benefits? York: Josepph Rowntree Foundation.

Smith, I. Lepine, E. and Taylor, M. 2007. Disadvantaged by Where You Live?Neighbourhood Governance in Contemporary Urban Policy. Bristol: Policy Press.

\section{Regulations:}

The 1945 Constitution of The Republic of Indonesia

Law Number 13 of 2011 on The Poverty Management.

\section{Journal:}

Woolcock, M. and Narayan, D. 2000. Social Capital: Implications for Development Theory, Research and Policy, World Bank Research Observer, Vol. 15: 225-249. 